\title{
New data on spiders and harvestmen (Arachnida: Aranei \& Opiliones) from Western Koryakia, Kamchatka Peninsula
}

\author{
Новые данные о пауках и сенокосцах (Arachnida: \\ Aranei \& Opiliones) Западной Корякии, Камчатка
}

\author{
Yuri M. Marusik $k^{1,2,5}$, Alexander S. Ryabukhin ${ }^{1,3}$ \\ \& Grigory V. Kuzminykh ${ }^{1,4}$ \\ Ю.М. Марусик ${ }^{1,2,5}$, А.С. Рябухин ${ }^{1,3}$, Г.В. Кузьминых ${ }^{1,4}$
}

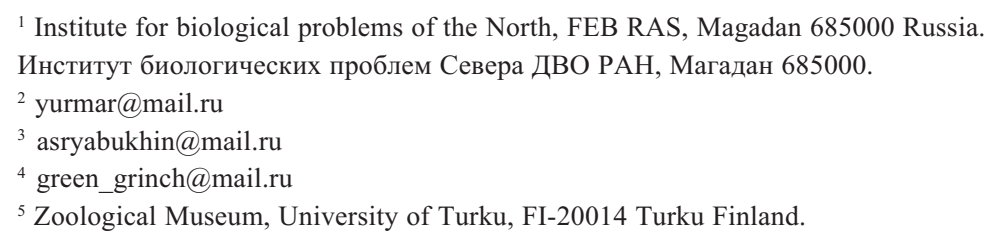

KEY WORDS: Northeast Asia, Far East Asia, new record, Kamchatka Province. КЛЮЧЕВЫЕ СЛОВА: Северо-Восток Азии, Дальний Восток, новая находка, Камчатский край.

ABSTRACT. Eighty-eight species of spiders and one species of harvestman are reported on from western Kamchatka. Eighty-five spider species and one Opiliones species are found in Koryakia for the first time. Among them, 31 species of spiders are new to Kamchatka Province; one of them, Ozyptila gertschi, is new to the far eastern Palaearctic. One species, Oedothorax trilobatus, which is well-known in the Nearctic, is new to Palaearctic. All interesting issues are commented upon. Three species Asperthorax borealis, Oedothorax trilobatus and Ozyptila gertschi are illustrated.

РЕЗЮМЕ. В западной Корякии, в окрестностях посёлка Тигиль отмечено 88 видов пауков и один вид сенокосца. Из них 85 видов пауков найдены в Корякии впервые, сенокосцы ранее не были известны в регионе. 31 вид пауков впервые зарегистрированы на Камчатке, из них Ozyptila gertschi впервые отмечается для Азии, а Oedothorax trilobatus впервые найден в Палеарктике. Приводятся список видов, все интресные находки прокомментированы. Asperthorax borealis, Oedothorax trilobatus и Ozyptila gertschi проиллюстрированны.

\section{Introduction}

Kamchatka is a poorly studied region in Eastern Palaearctic in respect of its spider fauna. Only some 190 species are known from there [Mikhailov, 1997, 2002]. For example, adjacent regions such as Sakhalin and Magadan have much more diverse fauna with 420 and 560 species, respectively [Marusik et al., 1992, 1993a]. More distant areas have also more diverse spider faunas ranging from 430 to 630 [Marusik, 2007]. Moreover, it is almost the only region east of Yenisei that has no check-list. It is evident that number of species in Kamchatka is much higher. Small number of reported species can be easily explained by lack of collected efforts during almost 70 years, and a corresponding lack of faunistic publications. The first publication about spiders of Kamchatka was published by Kulczyński [1885]. He reported over 130 species. The following three papers [Kulczyński, 1926; Schenkel, 1930; Sytshevskaja, 1935] added almost 70 species new to the fauna of peninsula. About two dozen species were reported in several taxonomic papers or faunistic publications dealing with whole Northern Asia [Marusik et al., 1992; Eskov \& Marusik, 1994; Mikhailov \& Marusik, 1995; Marsuik \& Koponen, 2010 , etc.]. At the same time few species were removed from the list because of synonymies or incorrect original identifications. Almost all species were reported from southeastern part of peninsula between Petropavlovsk-Kamchatski and Ust-Kamchatsk. Koryakia, a separate administrative unit within the Kamchatka Province, occupying northern and northwestern parts of Peninsula and adjacent territories, was almost entirely unknown. Only six species Allomengea scopigera (Grube, 1859), Bathyphantes eumenis (L. Koch, 1879), B. gulkana Ivie, 1969, B. pogonias Kulczyński, 1885, Collinsia holmgreni (Thorell, 1872) and Tmeticus affinis (Blackwall, 1855) have been reported from northwestern Koryakia in a check-list of northeastern Asia [Marusik et al., 1992]. Recently the second author had the opportunity to undertake an expedition to western Koryakia to collect beetles. During this expedition 
he collected almost 650 specimens of spiders and harvestmen belonging to 89 morphospecies. 34 of them are new to Kamchatka and almost all species (except three species, Allomengea scopigera, Bathyphantes eumenis and B. pogonias) are new to Koryakia. One species collected in Koryakia is new to Palaearctic and one species is new to Asia. Goal of this paper is to present a new data about spiders of Kamchatka Province and Koryakia in particular.

\section{Material and methods}

All spiders were collected by the second author in environs of Tigil Village (ca. 57 $46^{\prime} \mathrm{N} 158^{\circ} 40^{\prime} \mathrm{E}$ ) in western Koryakia (Map 1). All material was collected either by sifting litter or hand picking in lowland habitats. Although total number of samples taken in the field was 23 , we combined all of them into three groups according the type of habitats: 1) birch stands with Pinus pumula on south-east exposed slopes on low hills, 2) willow, and willow-alder stands on high river terrace and in river valley, and 3) boggy habitats. Few specimens were collected by hand picking or sweeping in several habitats. Pitfall traps we not used. Spiders were preserved in $75 \%$ alcohol. Material will be shared between the Zoological Museum of the Moscow State University and the Manchester Museum, University of Manchester, UK.

For all species new to Kamchatka and all unidentified specimens, we provide comments, and in three cases, references for most appropriate identification sources.

Specimens were photographed using an Olympus Camedia E-520 camera attached to an Olympus SZX16 stereomicroscope. The images were montaged using "CombineZM" image stacking software. Photographs were taken in dishes of different size with paraffin at the bottom. Different sized holes were made in the bottom to keep the specimens in the correct position.

Survey of species new to Kamchatka and unidentified species

\section{ARANEIDAE}

Araneus nordmanni (Thorell, 1870)

COMMENTS. This species is new to Kamchatka. It has a circum-Holarctic range and is known in the adjacent Magadan Area [Marusik et al., 1992], and most of North America [Levi, 1971; Dondale et al., 2003].

\section{Araneus yukon Levi, 1971}

COMMENTS. The species is new to Kamchatka. It has an East Siberian - northwestern Nearctic range and occurs from western Yakutia to south Yakutia [Marusik

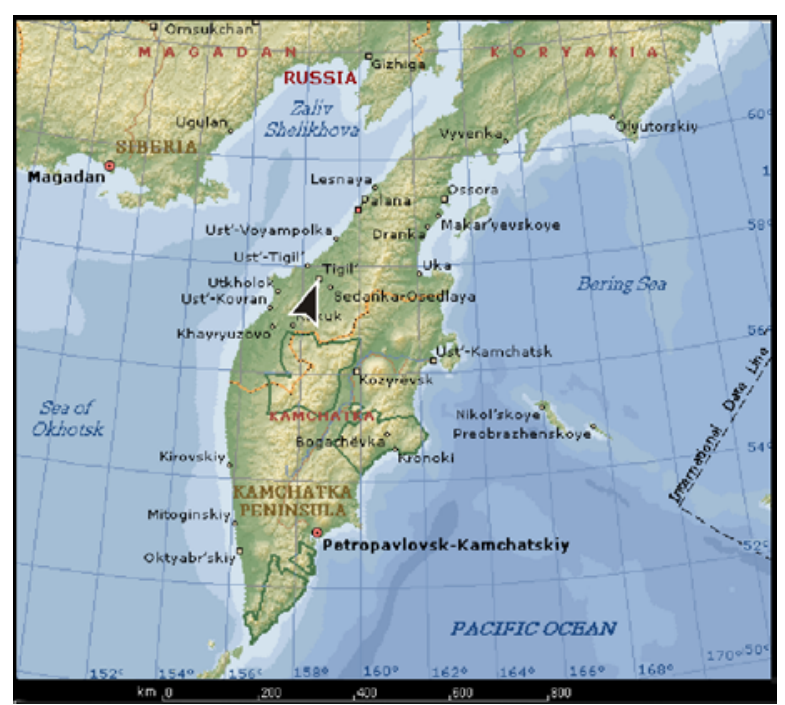

Map 1. Kamchatka Peninsula. Collecting locality arrowed.

Карта 1. Полуостров Камчатка. Место сбора материала указано стрелкой.

et al., 1993b], and north to Chaun Bay [Marusik et al., 1992]. In the Nearctic it was found in Alaska (personal data) and along western border of Yukon Territory [Dondale et al., 1997]. A. yukon is rather a common species in the adjacent Magadan Area. It is very likely that previous records of $A$. quadratus Clerk, 1757, from Kamchatka refer to this species.

\section{GNAPHOSIDAE}

\section{Haplodrassus soerenseni (Strand, 1900)?}

COMMENTS. The species is new to Kamchatka. It has trans-Palaearctic boreo-nemoral range [Marusik et al., 1996, 2000] and common in adjacent Magadan Area. Although identification of juvenile Haplodrassus specimens is almost impossible, we identified our specimens according to the size of subadult males and habitats. Other species occurring in adjacent Magadan Area are either larger or live in different habitats.

\section{LINYPHIIDAE}

\section{Agyneta mollis (O. Pickard-Cambridge, 1871)}

COMMENTS. This species in new to Kamchat$\mathrm{ka}$. It has a trans-Palaearctic-Alaskan range and is known in the adjacent Kuril Islands (personal data), although it is not known from the well- studied Magadan Area.

\section{Agyneta aff. trifurcata Hippa et Oksala, 1985}

COMMENTS. It is impossible to identify this species with certainty without males. 
Agyneta sp.

COMMENTS. Female specimens from Tigil Village may belong either to A. allosubtilis Loksa, 1965 or A. olivacea (Emerton, 1882). Females of these two species are very similar. The former species was already reported from Kamchatka [Mikhailov, 1997], and A. olivacea is common species in the northeastern Asia.

\section{Aphileta misera (O. Pickard-Cambridge, 1882)}

COMMENTS. This species is new to Kamchatka. It has a circum-Holarctic range. In adjacent Magadan Area it is known from the coastal part [Marusik, 2005].

\section{Asperthorax borealis Ono et Saito, 2001}

Figs $1-2$.

A. b. Ono \& Saito, 2001: 163, f. 6-11 ( $\left.\sigma^{7}+\right)$.

A. b. Ono et al., 2009: 274, f. 183-188 (O'O).

Comparative material examined: $2 \sigma^{\top} \sigma^{\top} 3$ of , RUSSIA, Khabarovsk Prov., env. of Khabarovsk, Bychikha Vill., secondary forest, 11.09.2005 (Y.M. Marusik)

COMMENTS. This species is new to Kamchatka and our record represents the most northeastern locality of the species. A. borealis was known from Hokkaido and Moneron Islands and in the environs of Khabarovsk [Marusik et al., 2007c]. The new locality is separated from the nearest locality by about 1700 $\mathrm{km}$. We compared specimens from Kamchatka and Khabarovsk and found no differences. It is worth mentioning that Ono \& Saito [2001] in the original description mentioned presence of Tm IV. Trichobothrium on metatarsus IV on the specimen from Kamchatka and those from Khabarovsk is absent.

Ceraticellus bulbosus (Emerton, 1882)

COMMENTS. This species is new to Kamchatka. It has a circum-Holarctic range and known in Magadan Area.

\section{Ceratinella sp. 1}

COMMENTS. So far, only one species, C. brevis (Wider, 1834) has been reported from Kamchatka. Our specimens have a dorsal abdominal scutum and might belong to this species, but the lack of a male does not allow us to identify this species with certainty.

\section{Ceratinella sp. 2}

COMMENTS. We were not able to identify this species. Unlike other species, male collected in Tigil Village lacks dorsal abdominal scutum.

Hilaira devitata Eskov, 1987

COMMENTS. It is new to Kamchatka. This species has a Siberian boreal range and occurs from Even-

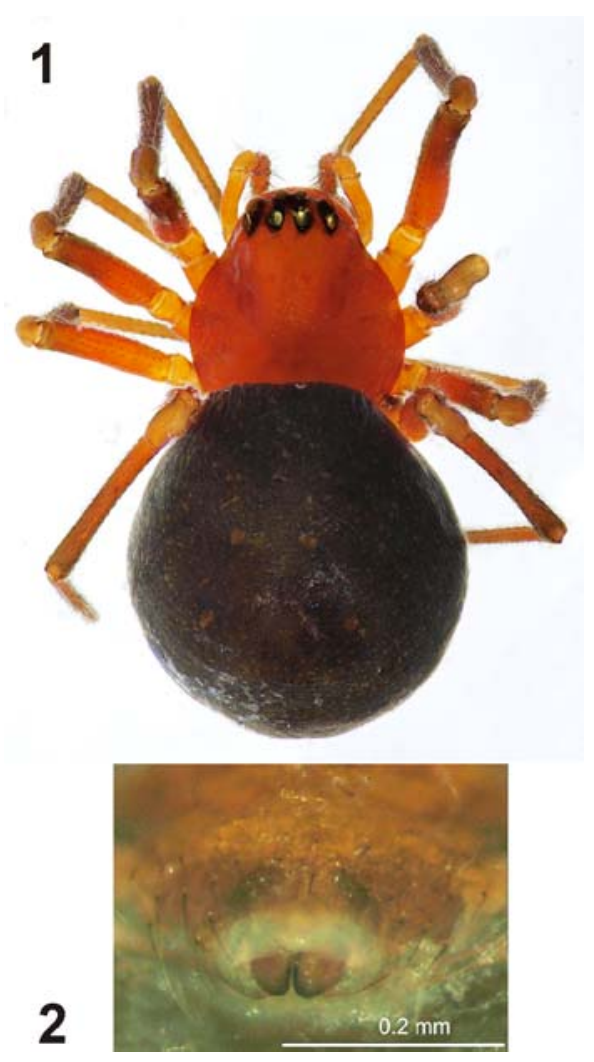

Figs 1-2. Female Asperthorax borealis: 1 - habitus, dorsal; 2 - epigyne, ventral.

Pис. 1-2. Самка Asperthorax borealis: 1 - внешний вид, сверху; 2 - эпигина, снизу.

kia east to Koryakia (the easternmost locality of the range) and southward to Amur River [Eskov, 1994].

Hilaira sibirica Eskov, 1987

COMMENTS. This species is new to Kamchatka. It has a Siberio-Alaskan hypoarctic range and known from Putorana Plateau southward to north Tuva, northeast to Chukotka [Marusik et al., 1992; Eskov, 1994]. In the Nearctic, $H$. sibirica was recorded from Alaska and Yukon Territory only [Dondale et al., 1997].

\section{Hybauchenidium gibbosum (Soerensen, 1898)}

COMMENTS. This species is new to Kamchatka. It has a northeastern Siberian - trans-Nearctic boreohypoarctic range. In Asia it was known earlier from the Magadan Area only, where it is very common [Marusik et al., 1992; Marusik, 2005].

\section{Hypselistes sp.}

COMMENTS. It is impossible to identify of the basis of females what species occurs in Koryakia. Epigynes in two species, H. jacksoni (O. Pickard-Cambridge, 1902) and H. kolymensis Marusik \& Leech, 1993, occurring in adjacent Magadan Area are identical. 

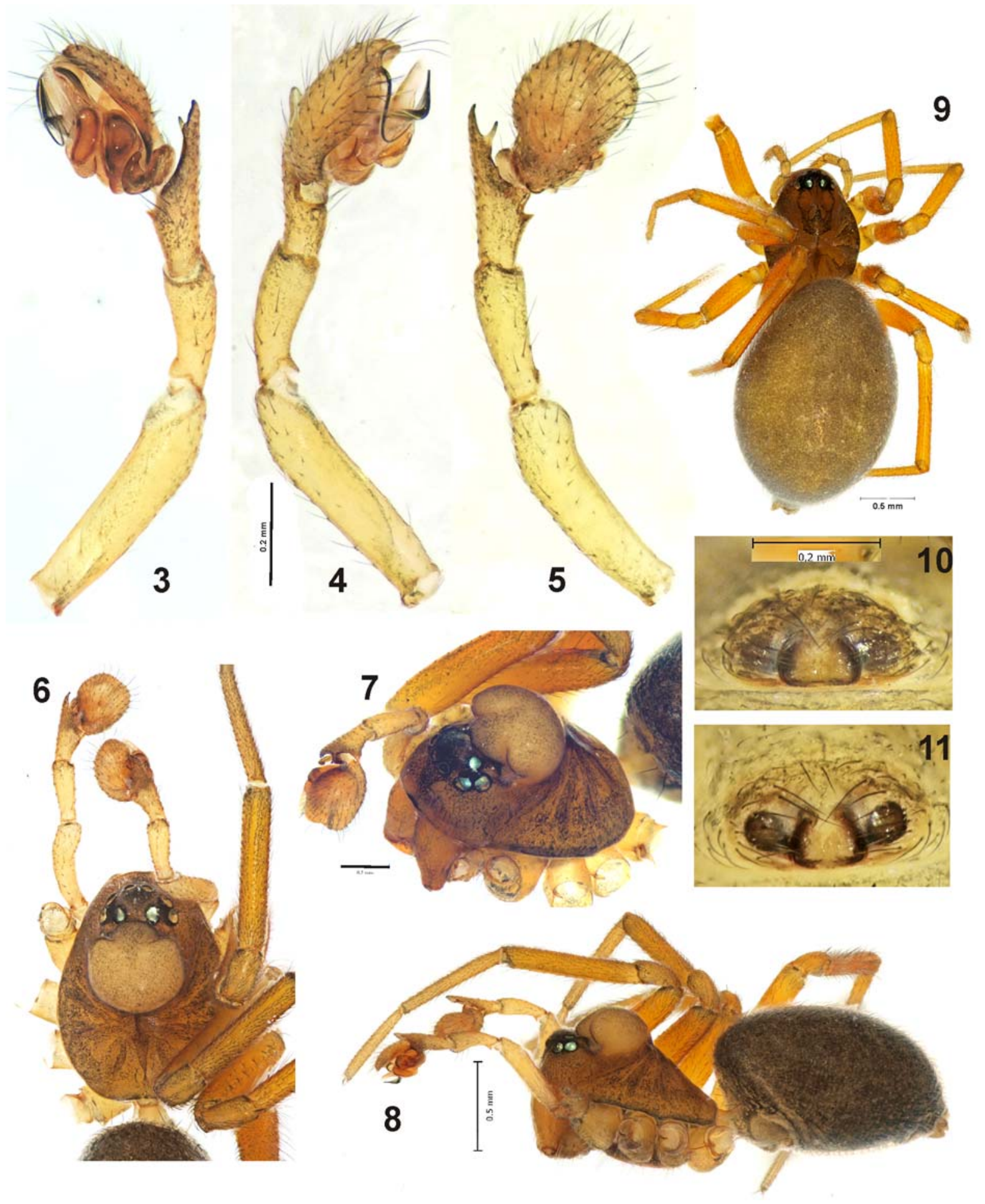

Figs 3-11. Habitus and copulatory organs of Oedothorax trilobatus: 3-5 - male palp, retrolateral, prolateral and dorsal, respectively; 6-7 - male prosoma, dorsal and dorso-lateral, respectively; 8- male, lateral; 9 - female, dorsal; 10-11 - epigyne, ventral.

Рис. 3-11. Внешний вид и совокупительные органы Oedothorax trilobatus: 3-5 - пальпа самца, ретролатерально, пролатерально и сверху, соответсвенно; 6-7 — головогрудь самца, сверху и сверху-сбоку, соответственно; 8 - самец, сбоку; 9 - самка, сверху; $10-11$ - эпигина, снизу. 


\section{Hypselistes semiflavus (L. Koch, 1879)}

COMMENTS. This species is new to Kamchatka. It has a Siberio-Alaskan boreal range and is known from South Yamal southward to Tuva, eastward to Kamchatka, northward to the Lena River mouth [Marusik \& Leech, 1993]. In the Nearctic it is known in the Yukon Territory [Marusik \& Leech, 1993]. It is known in the adjacent Magadan Area, but not on the Kuril Islands, where it is replaced with its sibling, $H$. basarukini Marusik \& Leech, 1993.

\section{Lophomma vaccinii (Emerton, 1926)}

COMMENTS. This species is new to Kamchatka. It has a Siberio-Nearctic range and is known in the adjacent Magadan Area and the North Kuril Islands [Marusik et al., 2007b].

\section{Micrargus herbigradus (Blackwall, 1854)}

COMMENTS. This species is new to the Kamchatka Peninsula. It has a Palaearctic range and is known in the adjacent North Kuril Islands [Mikhailov, 1997].

\section{Oedothorax trilobatus (Banks, 1896)}

Figs 3-11.

O. t.: Paquin \& Dupérré, 2003: 115, f. 1190-1193 (○º).

COMMENTS. This species is new to the Palaearctic and its record from Kamchatka is the westernmost in the range. Earlier it was known exclusively from the Nearctic. In the Nearctic, O. trilobatus is reported from Alaska to Québec [Buckle et al., 2001]. Males of this species can be easily recognized because of the characteristic shape of the cephalic part of carapace and shape of the palp. The tibia has dorsal, bifid apophysis with prolateral arm smaller than retrolateral. In all other Erigoninae know to us, the retrolateral arm is larger than prolateral. The bulbus is also very specific. Females of O. trilobatus can be confused with several Palaearctic Oedothorax species. Because Palaearctic Oedothorax species are absent in easternmost Asia, there are no real difficulties with identification of $O$. trilobatus. Judging from the shape of male carapace and male palp (tibia and bulbus), this species is distantly related the type species of the genus $O$. gibbosus (Blackwall, 1841), and possibly should be treated as being in a separate genus. Occurrence of this species in other parts of Kamchatka and adjacent Northern Kuril islands is very likely.

Paratmeticus bipunctis (Bösenberg et Strand, 1906)

COMMENTS. Until recently this species and genus were unknown in Kamchatka. The species was reported from the peninsula by Marusik \& Koponen [2010] and a new monotypic genus was erected for this species. P. bipunctis occurs from Kamchatka south to Japan. All records of this species, except those from
Kamchatka, are on islands. The record from Koryakia is the most northern in the range.

\section{Pelecopsis parallela (Wider, 1834)}

COMMENTS. This species is new to Kamchatka. It has a trans-Palaearctic range. This is only record of this species outside the Palaearctic - Western Greenland [Marusik et al., 2007a].

\section{Perregrinus deformis (Tanasevitch, 1982)}

COMMENTS. This species is new to Kamchatka. It has a Siberio-Nearctic range and is known in the adjacent Magadan Area.

\section{Praestigia kulczynskii Eskov, 1979 ?}

COMMENTS. This species is new to Kamchatka. It has a Siberio-Nearctic range and is known in the adjacent Magadan Area and on Sakhalin Island [Marusik et al., 2008].

\section{Sciastes dubius (Hackman, 1954)}

COMMENTS. This species is new to Kamchatka. It has a northeast Siberian - Nearctic range. In Asia it is known only from the Magadan Area, where it was found in the coastal part only [Marusik, 2005]. In the Nearctic it is known from the Yukon Territory to Newfoundland [Buckle, 2001].

\section{Semlicola lapponicus (Holm, 1939)}

COMMENTS. This species is new to Kamchatka. It has a trans-Palaearctic-Alaskan hypoarctic range and occurs from northern Scandinavia eastward to Alaska [Saaristo \& Eskov, 1996,southward to northern Cisokhotia [Marusik, 2005].

\section{Tibioploides pacificus Eskov et Marusik, 1991}

COMMENTS. This species is new to Kamchatka. It has an East Siberian boreal range [Eskov, 1994]. It was reported from the north part of Khabarovsk Province, upper Kolyma and central Sakhalin. The record from Koryakia is the easternmost in the range.

Walckenaeria kochi (O. Pickard-Cambridge, 1872)

COMMENTS. This species is new to Kamchatka. Its full range is unclear. The species is unknown between Evenkia (Middle Siberia) and Kamchatka [cf. Eskov, 1994]. Recently this species was reported from Simushir Island (Middle Kuril Islands) by Tanasevitch [2007]. On the other hand, this species seems present in the Nearctic under the name $W$. fusciceps Millidge, 1983. Buckle [cf. Buckle et al., 2001] consider these names as synonyms. Moreover $W$. kochi was reported from Québec [Paquin \& Dupérré, 2003]. 

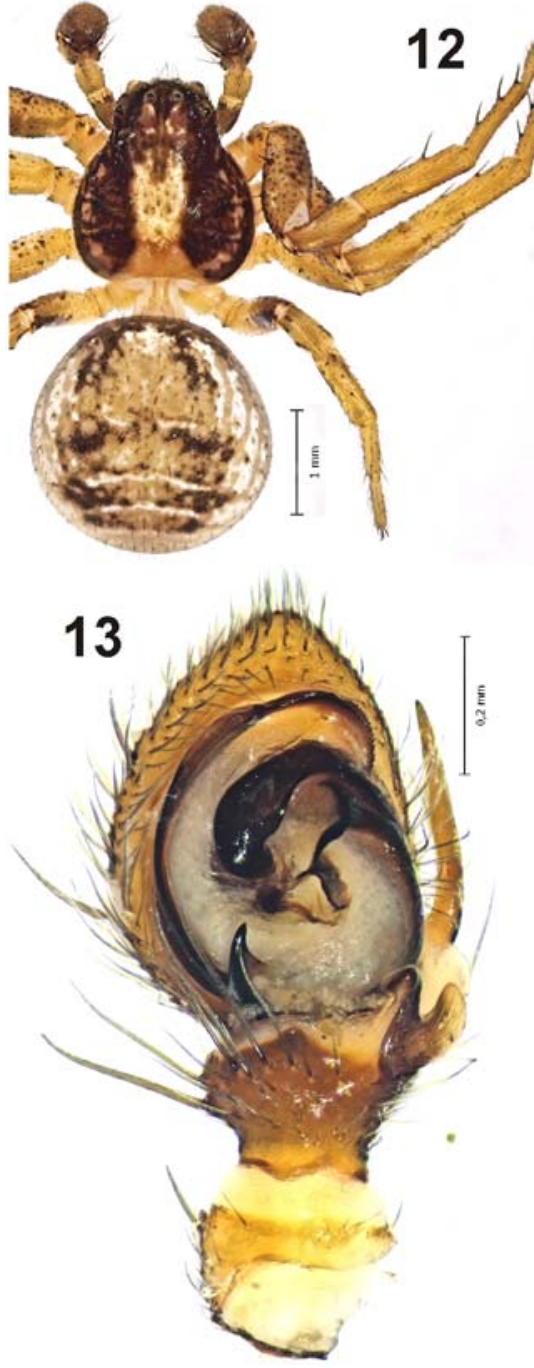

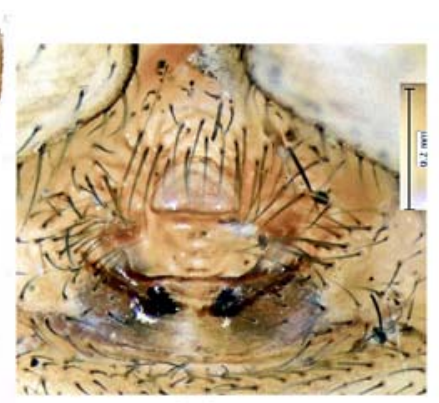

16

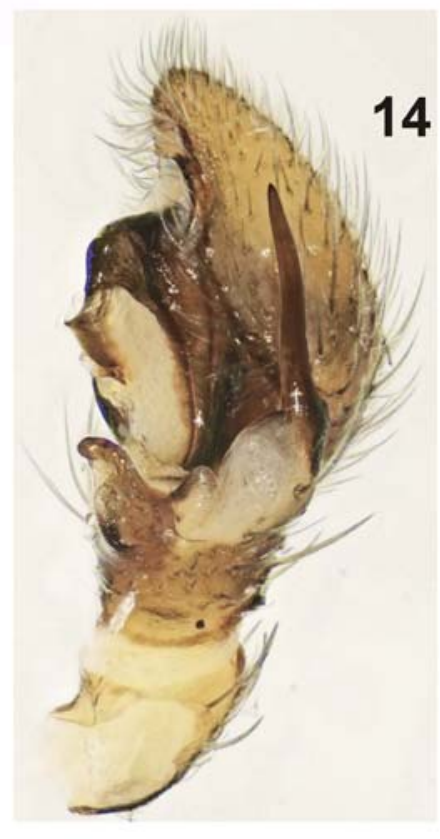

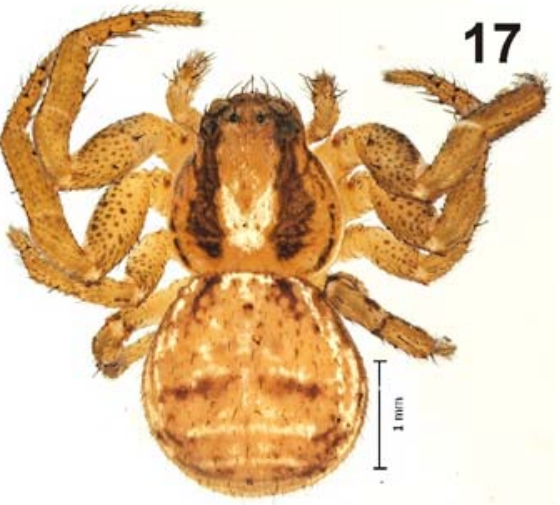

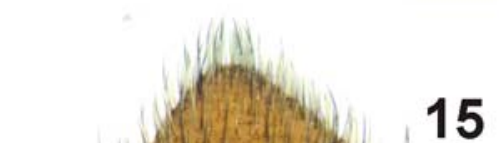

15

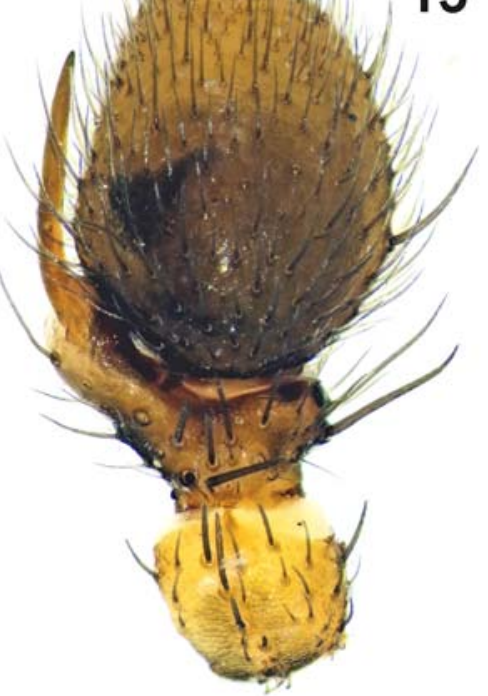

Figs 12-17. Habitus and copulatory organs of Ozyptila gertschi: 12, 17 - male and female habitus, dorsal; 13-15 - male palp, ventral, retrolateral and dorsal, respectively; 16 - epigyne, ventral.

Рис. 12-17. Внешний вид и совокупительные органы Ozyptila gertschi: 12, 17 - самец и самка, внешний вид, сверху; 13-15 пальпа самца, снизу, ретролатерально и сверху; 16 - эпигина, снизу.

Walckenaeria nudipalpis (Westring, 1851)

COMMENTS. This species is new to Kamchatka. It has a trans-Palaearctic range and is known in adjacent Northern Sakhalin [Eskov, 1994] and North Kuril islands (personal data). The record from Koryakia is the northernmost in East Asia.

Walckenarianus aimakensis Wunderlich, 1995

COMMENTS. This species and this genus are new to Kamchatka. The genus is monotypic and was earlier known from Tuva to Magadan Area [Marusik et al., 2000]. The record from Tigil Village is the easternmost in the range.

\section{LYCOSIDAE}

Pirata aff. canadensis Dondale et Redner, 1981

COMMENTS. A single male found in Koryakia is very similar to the Nearctic $P$. canadensis and possibly conspecific with it. This matter will be considered in a revision of east Asian Pirata (Omelko et al., in preparation). The specimen from Tigil Village is also similar to $P$. insularis Emerton, 1885, but is smaller in size (same as in P. canadensis). 


\section{THERIDIIDAE}

\section{Canalidion montanum (Emerton, 1882)}

COMMENTS. This species is new to Kamchatka. It has a Holarctic range and known in the adjacent Magadan Area in Coastal parts [Marusik, 2005].

Robertus lyrifer Holm, 1939

COMMENTS. This species is new to Kamchatka. It has a Palaearctic range and known in the adjacent Magadan Area and Chukotka [Marusik, 2005]. It seems that the record from Koryakia is the southernmost in the range.

\section{Robertus aff. lyrifer Holm, 1939}

COMMENTS. It is likely a new species. It is smaller in size in comparison to $R$. lyrifer and has slightly different copulatory organs. This species will be considered in a special taxonomic publication.

\section{Robertus ungulatus Vogelsanger, 1944}

COMMENTS. This species is new to Kamchatka. It has a trans-Palaearctic range and occurs from Central Europe to Koryakia, which is the northeasternmost locality in the range. This species has a disjunction between the Alps and Tuva, and Tuva and Far East [Marusik et al., 2000]. It is unknown in Magadan Area.

\section{Rugathodes aurantius (Emerton, 1915)}

COMMENTS. This species is new to Kamchatka. It has an almost circum-Holarctic range and occurs from Karelia to Kamchatka and across whole northern Nearctic. $R$. aurantius was reported in adjacent Magadan Area in coastal parts [Marusik, 2005] and in Sakhalin.

\section{Thymoites bellissimus (L. Koch, 1879)}

COMMENTS. This species in new to Kamchatka. It has a trans-Palaearctic range and is known from Fennoscandia to Chukotka [Marusik et al., 2000]. It is known in the adjacent Magadan Area.

\section{THOMISIDAE}

Ozyptila gertschi Kurata, 1944

Figs 12-17.

O. g.: Paquin \& Dupérré, 2003: 230, f. 2570-2573 (Оౌo).

COMMENTS. This species is new to Kamchatka and entire Asia. Earlier it was known from throughout Nearctic and in Europe from Germany to the Urals. It was never reported from Siberia or other Asian regions. It seems that it has disjunction between Ural and Kamchatka. Males of $O$. gertschi can be easily identi- fied owing to a very long retrolateral tibial apophysis stretching upward, and shape of the tegulum with a claw-like outgrowth in the basal part on the prolateral side (Fig. 11) which is absent in all other Ozyptila. Females of this species are similar to several other species occurring in Far East, such as $O$. sincera Kulczyński, 1926, or O. trux (Blackwall, 1846). From these species it can be distinguished by the longer and wider scape of the epigyne (Fig. 14).

\section{Xysticus britcheri Gertsch, 1934}

COMMENTS. This species is new to Kamchatka. It has an almost circum-Holarctic range and is known from Archangelsk Area to Chukotka and throughout the Nearctic. $X$. britcheri is very common in adjacent Magadan Area.

\section{Zora sp.}

COMMENTS. So far, two species of Zora, Z. spinimana (Sundevall, 1832) and Z. nemoralis (Blackwall, 1861), are known in Kamchatka. We cannot place our specimens to either of these species because of the lack of adult males. It is likely that the record of Z. nemoralis in the peninsula refers to undescribed species.

\section{Conclusions}

Eighty-eight species of spiders and one harvestman species were found in western Koryakia in 2010. Only three species of spiders were previously reported from Koryaki All records, old and new, give a total number of spider species found in Koryakia as 91. Four of these records are of special biogeographical interest: Asperthorax borealis, Oedothorax trilobatus, Walckenaeria kochi, and Ozyptila gertschi. None of these species, except for $A$. borealis, was known in Asia. The nearest known locality of $A$. borealis is the environs of Khabarovsk, which is ca $1700 \mathrm{~km}$ from Tigil Village. Oedothorax trilobatus has never been reported in the Palaearctic, although it is widespread in the Nearctic. The latter two species have wide disjunction between the Urals and Kamchatka. In addition to Oedothorax trilobatus, there is one more species that seems to be new to the Palaearctic, Pirata canadensis.

To our mind, the real diversity of spiders in Koryakia may be close to 400 species. Some 400 species of spiders are reported from Northern Cisokhotia (from 138 to $163^{\circ} \mathrm{E}$ ) and same number of species occurs in continental parts of Magadan Area [Marusik, 2005]. We are not providing biogeographical analysis of Koryakian spiders, mainly because the species found so far in the region represent only small (not larger than one quarter) fraction of the possible species diversity.

We suspect that only two species of harvestmen occur in Koryakia, like in Magadan Area: Mitopus morio (Fabricius, 1779) (found in Tigil Village) and Homolophus arcticus Banks, 1893. The latter species 
Table 1. Material examined and spatial distribution of spiders collected near Tigil Village: 1) birch stands with Pinus pumula on south-west exposed slopes on low hills; 2) willow, and willow-alder stands on high river terrace and river valley; 3 ) boggy habitats and 4) varia.

Таблица 1. Исследованный материал и биотопическое распространение пауков в окрестностях п. Тигиль: 1) березняки с примесью кедрового стланика на пологом склоне ЮЗ экспозиции; 2) ивняки, ивняки с ольхой в долине реки; 3) заболоченные участки и 4) разное.

\begin{tabular}{|c|c|c|c|c|}
\hline Species & 1 & 2 & 3 & 4 \\
\hline \multicolumn{5}{|l|}{ Araneidae } \\
\hline Araneus alsine (Walckenaer, 1802) & 1 운 & & & \\
\hline Araneus marmoreus Clerck, 1757 & & & & $8+40^{7} 1 \mathrm{j}$ \\
\hline Araneus nordmanni (Thorell, 1870)* & & & & 1 우 \\
\hline Araneus yukon Levi, 1971* & & & & $10^{x}$ \\
\hline \multicolumn{5}{|l|}{ Clubionidae } \\
\hline Clubiona kulczynskii Lessert, 1905 & & 19 & & \\
\hline Clubiona latericia Kulczyński, 1926 & & & $2+1 \mathrm{j}$ & \\
\hline \multicolumn{5}{|l|}{ Gnaphosidae } \\
\hline Haplodrassus soerenseni (Strand, 1900)?* & & $2 \mathrm{j}$ & & \\
\hline \multicolumn{5}{|l|}{ Linyphiidae } \\
\hline Agyneta mollis (O. Pickard-Cambridge, 1871)* & & & 7 욱 & \\
\hline Agyneta aff trifurcata Hippa et Oksala, 1985 & & & 1 운 & \\
\hline Agyneta sp. & 1 운 & 18 우 & & \\
\hline Allomengea scopigera $(\text { Grube, } 1859)^{\mathrm{k}}$ & & $20^{7}+$ & & \\
\hline Anguliphantes karpinskii (O. Pickard-Cambridge, 1873) & 1 운 & $2+$ & & \\
\hline Aphileta misera (O. Pickard-Cambridge, 1882)* & & $1+9$ & & \\
\hline Asperthorax borealis Ono et Saito, $2001^{*}$ & 1 운 & & & \\
\hline Bathyphantes eumenis (L. Koch, 1879) ${ }^{\mathrm{k}}$ & & $83+$ & 5 우 & \\
\hline Bathyphantes gracilis (Blackwall, 1841) & & & 1 운 & \\
\hline Bathyphantes pogonias Kulczyński, $1885^{\mathrm{k}}$ & & $10^{\top} 6$ 운 & 1 우 & \\
\hline Centromerus sylvaticus (Blackwall, 1841) & & $10^{x} 6+$ & & \\
\hline Ceraticellus bulbosus (Emerton, 1882)* & & & $11+$ & \\
\hline Ceratinella sp. 1 & $4+$ & & & \\
\hline Ceratinella sp. 2 & & 19 & $10^{\top} 193 \mathrm{j}$ & \\
\hline Dicymbium libidinosum (Kulczyński, 1926) & & $10^{\top} 12$ 운 & $4+$ & \\
\hline Diplocentria bidentata (Emerton, 1882) & 1 운 & $30^{7} 12$ 운 & 1 운 & \\
\hline Erigone atra Blackwall, 1833 & & & $1+$ & \\
\hline Estrandia grandaeva (Keyserling, 1886) & & $3+$ & & $3+$ \\
\hline Flagelliphantes flagellifer (Tanasevitch, 1987) & & $1+9$ & & \\
\hline Gnathonarium sp. & & 19 & $20^{\top} 4$ 우 & \\
\hline Gnathonarium taczanowskii (O. Pickard-Cambridge, 1873) & & $2 q$ & & \\
\hline Hilaira canaliculata (Emerton, 1915) & & & $12+$ & \\
\hline Hilaira devitata Eskov, $1987 *$ & & 1 운 & & \\
\hline Hilaira herniosa (Thorell, 1875) & & 39 & & \\
\hline Hilaira sibirica Eskov, 1987* & & $19+$ & 19 & \\
\hline Hybauchenidium gibbosum (Soerensen, 1898)* & & 19 & & \\
\hline Hylyphantes graminicola (Sundevall, 1830) & & $20^{7}+9$ & & \\
\hline Hypselistes $\mathrm{sp}$. & & $4+$ & & \\
\hline Hypselistes semiflavus (L. Koch, 1879)* & & & $30^{7} 5$ 운 & \\
\hline Improphantes complicatus (Emerton, 1882) & & $1+9$ & & \\
\hline Kaestneria anceps (Kulczyński, 1885) & & & $10^{\top} 3+1 \mathrm{j}$ & \\
\hline Lophomma vaccinii (Emerton, 1926)* & & $2+9$ & $10^{\top} 2+$ & \\
\hline Maso sundevalli (Westring, 1851) & & & $10^{\top} 29$ & \\
\hline Micrargus herbigradus (Blackwall, 1854)* & & $1+9$ & & \\
\hline Microlinyphia pusilla (Sundevall, 1830) & & & $3+1 \mathrm{j}$ & \\
\hline
\end{tabular}


Table 1 (continuing) Таблица 1 (продолжение)

\begin{tabular}{|c|c|c|c|c|}
\hline $\begin{array}{r}\text { Species } \\
\end{array}$ & 1 & 2 & 3 & 4 \\
\hline Minyrioloides affine (Schenkel, 1930) & & & 19 & \\
\hline Mughiphantes taczanowskii (O. Pickard-Cambridge, 1873) & & $3+$ & & \\
\hline 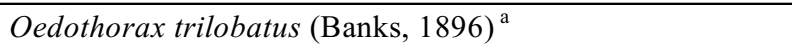 & & & $480^{2}+$ & \\
\hline Oreonetides vaginatus (Thorell, 1872) & & 29 & & \\
\hline Oryphantes bipilis (Kulczyński, 1885) & & $10^{\top} 22+$ & $4+$ & \\
\hline Paratmeticus bipunctis (Bösenberg et Strand, 1906) & $10^{7}$ & 19 & & \\
\hline Pelecopsis parallela (Wider, 1834)* & & & 19 & \\
\hline Perregrinus deformis (Tanasevitch, 1982)* & & $20^{\top} 34+9$ & & \\
\hline Phlattothrata parva (Kulczyński, 1926) & & 1 우 & & \\
\hline Porrhomma montanum Jackson, 1913 & & $2 q$ & & \\
\hline Praestigia kulczynskii Eskov, 1979 ?* & & & $2 q$ & \\
\hline Sciastes dubius (Hackman, 1954)* & & 69 & & \\
\hline Semlicola lapponicus (Holm, 1939) & & $10^{7} 4+$ & & \\
\hline Stemonyphantes sibiricus (Grube, 1861) & $1+2 \mathrm{j}$ & & & \\
\hline Tenuiphantes alacris (Blackwall, 1853) & & $1+$ & & \\
\hline Tenuiphantes mengei (Kulczyński, 1887) & & $1+9$ & & \\
\hline Tenuiphantes nigriventris (L. Koch, 1879) & & $20^{7} 49$ & & \\
\hline Tibioploides pacificus Eskov et Marusik, 1991* & & $20^{7} 29$ & & \\
\hline Tibioplus diversus (L. Koch, 1879) & 19 & & & \\
\hline Tunagyna debilis (Banks, 1892) & & $10^{7} 3$ + & & \\
\hline Walckenaeria cuspidata Blackwall, 1833 & & $30^{7} 23 q$ & & \\
\hline Walckenaeria karpinskii (O. Pickard-Cambridge, 1873) & 29 & 49 & & \\
\hline Walckenaeria kochi (O. Pickard-Cambridge, 1872) & & & $10^{\top} 14+$ & \\
\hline Walckenaeria nudipalpis (Westring, 1851)* & $3+$ & & 1 운 & \\
\hline Walckenarianus aimakensis Wunderlich, 1995* & & & $20^{7} 77^{\circ}$ & \\
\hline \multicolumn{5}{|l|}{ Liocranidae } \\
\hline Agroeca ornata Banks, 1892 & $1+1 \mathrm{j}$ & $20^{7}$ & & \\
\hline \multicolumn{5}{|l|}{ Lycosidae } \\
\hline Pardosa riparia (C.L. Koch, 1847) & & & $2 q$ & \\
\hline Pardosa tesquorum (Odenwall, 1901) & & & & $1+9$ \\
\hline Pirata aff. canadensis Dondale et Redner, 1981* & & & $10^{x}$ & \\
\hline \multicolumn{5}{|l|}{ Philodromidae } \\
\hline Tibellus maritimus (Menge, 1875) & & & 19 & \\
\hline \multicolumn{5}{|l|}{ Salticidae } \\
\hline Heliophanus camtschadalicus Kulczyński, 1885 & & & $1+$ & \\
\hline Sitticus caricis (Westring, 1861) & & & $2 \sigma^{7} 1+1 j$ & \\
\hline \multicolumn{5}{|l|}{ Tetragnathidae } \\
\hline Pachygnatha clercki Sundevall, 1823 & $1 \mathrm{j}$ & & $20^{x} 1+10 \mathrm{j}$ & \\
\hline Tetragnatha extensa (Linnaeus, 1758) & & & $1 \mathrm{j}$ & 19 \\
\hline \multicolumn{5}{|l|}{ Theridiidae } \\
\hline Canalidion montanum (Emerton, 1882)* & & & & $10^{7}$ \\
\hline Enoplognatha caricis (Fickert, 1876) & & $2 \mathrm{j}$ & $2 \mathrm{j}$ & \\
\hline Robertus lividus (Blackwall, 1836) & 6 우 & 1 우 & & \\
\hline Robertus lyrifer Holm, 1939* & & & $1+$ & \\
\hline Robertus aff. lyrifer Holm, 1939* & & & $20^{\top} 29$ & \\
\hline Robertus ungulatus Vogelsanger, 1944* & & & $20^{7} 15+1 \mathrm{j}$ & \\
\hline
\end{tabular}


Table 1 (continuing) Таблица 1 (продолжение)

\begin{tabular}{|c|c|c|c|c|}
\hline Species & 1 & 2 & 3 & 4 \\
\hline Rugathodes aurantius (Emerton, 1915)* & $20^{7}+$ & $30^{7} 4+3 j$ & & \\
\hline Thymoites bellissimus (L. Koch, 1879)* & & $1\left(O^{7}\right)$ & $1\left(0^{7}\right)$ & \\
\hline \multicolumn{5}{|l|}{ Thomisidae } \\
\hline Ozyptila gertschi Kurata, $1944^{\mathrm{a}}$ & & & $20^{7} 7+8 j$ & \\
\hline Xysticus britcheri Gertsch, 1934* & & & $20^{\top} 3 \mathrm{j}$ & \\
\hline \multicolumn{5}{|l|}{ Zoridae } \\
\hline Zora sp. & $2+3 \mathrm{j}$ & $1+2 \mathrm{j}$ & & \\
\hline \multicolumn{5}{|l|}{ Zygiellidae } \\
\hline Parazygiella dispar (Kulczyński, 1885) & & & & $1 \mathrm{j}$ \\
\hline \multicolumn{5}{|l|}{ Opiliones/Phalangiidae } \\
\hline Mitopus morio (Farbricius, 1779) & $1 \mathrm{j}$ & $9 \mathrm{j}$ & $5 \mathrm{j}$ & \\
\hline
\end{tabular}

Species new to fauna of Kamchatka are marked with asterisk $(*)$, species previously known to Koryakia are marked with ${ }^{\mathrm{k}}$, and species new either to Asia or Palaearctic are marked by a. "J" means juvenile.

is known from Kamchatka Peninsula on the eastern part [Tschemeris, 2000]. There are three species of Opiliones in Kamchatka. The third species is Mitopus mongolicus mongolicus Roewer, 1912.

ACKNOWLEDGEMENTS. We thank Seppo Koponen who arranged YM's stay in Turku and allowed the use of local facilities (digital camera attached to microscope). We thank also Mikhail Omelko (Vladivostok) who helped with identification of Pirata species. Special thanks to Robin Leech, who corrected English of the final draft and edited this work.

This work was supported in part by the RFFI grant \# 0904-01365 and FEB RAS grants \# 10-III-Д-06-020 and \# 11III-B-06-010.

\section{References}

Buckle D.J., Carroll D., Crawford R.L., Roth V.D. 2001. Linyphiidae and Pimoidae of America north of Mexico: checklist, synonymy, and literature // P. Paquin \& D.J. Buckle (eds.). Contributions à la connaissance des Araignées (Araneae) d'Amérique du Nord. Fabreries. Supplément 10. P.89-191.

Dondale C.D., Redner J.H., Marusik Yu.M.1997. Spiders (Araneae) of the Yukon // H.V. Danks (ed.). Insects of the Yukon. Ottawa. P.73-113.

Dondale C.D., Redner J.H., Paquin P., Levi H.W. 2003. The orbweaving spiders of Canada and Alaska. Araneae: Uloboridae, Tegragnathidae, Araneidae, Theridiosomatidae. The insects and arachnids of Canada. Part 23. 371 p.

Eskov K.Yu. 1994. Catalogue of the linyphiid spiders of northern Asia (Arachnida, Araneae, Linyphiidae). Sofia-Moscow: PENSOFT Publ. 144 pp.

Eskov K.Yu., Marusik Yu.M. 1994. New data on the taxonomy and faunistics of North Asian linyphiid spiders (Aranei, Linyphiidae) // Arthropoda Selecta. Vol.2 (for 1993). No.4. P.41-79.

Kulczyński W. 1885. Araneae in Camtschadalia a Dre B. Dybowski collectae // Pam. Wydz. matem.-przyz. Akad. Umiej. Krakow. T.11. P.1-60.

Kulczyński W. 1926. Arachnoidea Camtschadalica // Annu. Zool Mus. AN URSS. Vol.27. No.1. P.29-72.

Levi H.W. 1971. The diadematus group of the orb-weaver genus Araneus north of Mexico (Araneae: Araneidae) // Bull. Mus. Comp. Zool. Vol.141. No.4. P.131-179.
Marusik Yu.M. 2005. [Arachnids (Arachnida: Aranei, Opiliones) of northern Cisokhotia] // Euroasian Entomological Journal. Vol.4. No.3. P.187-208 [in Russian, with English summary].

Marusik Y.M. 2007. [Spiders (Arachnida: Aranei) of the Asian part of Russia: taxonomy, fauna, zoogeography]. Autoreferate of Dr. Biol. Sci. Dissertation. St.Petersburg: St.Petersburg State Univ. 36 p. [in Russian]

Marusik Yu.M., Eskov K.Yu., Logunov D.V., Basarukin A.M. 1993a. A check-list of spiders (Arachnida, Aranei) from Sakhalin and Kurile Islands // Arthropoda Selecta. Vol.1 (for 1992). No.4. P.73-85.

Marusik Yu.M., Koponen S. 2010. A review of the Holarctic genus Tmeticus Menge, 1868 (Araneae, Linyphiidae), with a description of a new genus // ZooKeys. No.59. P.15-37.

Marusik Yu.M., Böcher J., Koponen S. 2007a. The collection of Greenland spiders (Aranei) kept in the Zoological Museum, University of Copenhagen // Arthropoda Selecta. Vol.15. No.1. P.59-80.

Marusik Yu.M., Eskov K.Yu., Kim J.P. 1992. A check-list of spiders (Aranei) of Northeast Asia // Korean Arachnol. Vol.8. No.1-2. P.129-158.

Marusik Yu.M., Eskov K.Yu., Koponen S., Vinokurov N.N. 1993b. A check-list of the spiders (Aranei) of Yakutia, Siberia // Arthropoda Selecta. Vol.2. No.2. P.63-79.

Marusik Yu.M., Gnelitsa V.A., Koponen S. 2007b. A survey of Holarctic Linyphiidae (Araneae). 4. A review of the erigonine genus Lophomma Menge, 1868 // Arthropoda Selecta. Vol.15. No.2. P.153-171.

Marusik Yu.M., Tanasevitch A.V., Kurenshchikov D.K., Logunov D.V. 2007c. A check-list of the spiders (Araneaea) of the Bolshekhekhtsyrski Nature Reserve, Khabarovsk Province, the Russian Far East // Acta Arachnologica Sinica. Vol.16. No.1. P.37-64.

Marusik Yu.M., Gnelitsa V.A., Koponen S. 2008: A survey of Holarctic Linyphiidae (Araneae). 3. A review of the genus Praestigia Millidge, 1954 // Bull. Br. arachnol. Soc. Vol.14. Part 5. P.213-231.

Marusik Yu.M., Hippa H., Koponen S. 1996. Spiders from the Altai area, South Siberia// Acta Zoologica Fennica. Vol.201. P.11-45.

Marusik Yu.M., Leech R. 1993. The spider genus Hypselistes, including two new species, from Siberia and the Russian Far East (Araneida: Erigonidae) // Can. Entomol. Vol.125. P.1115-1126.

Marusik Yu.M., Logunov D.V., Koponen S. 2000. Spiders of Tuva, South Siberia. Magadan: IBPN FEB RAS. 252 pp.

Mikhailov K.G. 1997. Catalogue of the spiders of the territories of the former Soviet Union (Arachnida, Aranei). Moscow: Zoological Museum of the Moscow State University. 416 pp. 
Mikhailov K.G. 2002. The spider fauna of Russia and other postSoviet republics: a 2000 update // S. Toft \& N. Scharff (eds.). European Arachnology 2000. Proceedings of the $19^{\text {th }}$ European Colloquium of Arachnology, Århus 17-22 July 2000. P.255259.

Mikhailov K.G., Marusik Yu.M. 1995. [Spiders of the north-east USSR. Families Clubionidae, Zoridae, Liocranidae and Gnaphosidae (genus Micaria) (Arachnida, Aranei)] // Entomologicheskiye issledovaniya na Severo-Vostoke SSSR. Vladivostok. Vol.2 (for 1991). P.90-113 [in Russian].

Ono H., Matsuda M., Saito H. 2009. Linyphiidae, Pimoidae // H. Ono (ed.). [The Spiders of Japan with keys to the families and genera and illustrations of the species]. Kanagawa: Tokai Univ. Press. P.253-344 [in Japanese].

Ono H., Saito H. 2001. New species of the family Linyphiidae (Arachnida, Araneae) from Japan // Bull. natn. Sci. Mus. Tokyo (A). Vol.27. P.159-203.

Paquin P., Dupérré N. 2003. Guide d'identification des araignées de Québec // Fabreries. Suppl.11. P.1-251.
Saaristo M.I., Eskov K.Y. 1996. Taxonomy and zoogeography of the hypoarctic erigonine spider genus Semljicola (Araneida, Linyphiidae) // Acta Zool. Fennica. Vol.201. P.47-69.

Schenkel E. 1930. Die Araneiden der schwedischen KamtchatkaExpedition 1920-1922 // Ark. Zool. Bd.21A. Nr.15. S.1-33.

Sytschevskaya V.J. 1935. Étude sur les araignées de la Kamtchatka // Folia zool. hydrobiol. Vol.8. P.80-103.

Tanasevitch A.V. 2007. On a small linyphiid spider collection from Simushir Island, Kurile Islands, Russia, with notes on Stemonyphantes sibiricus Grube (Aranei: Linyphiidae) // Arthropoda Selecta. Vol.15 (for 2006). No.3. P.255-258.

Tschemeris A.N. 2000. Contribution to the knowledge of the harvestman fauna in the Russian Far East and Eastern Siberia (Arachnida: Opiliones) // Arthropoda Selecta. Vol.9. No.1. P.31-49.

Responsible editor R. Leech 